\title{
Analisis Pengaruh Mobile Application Dalam Menunjang Keberhasilan Wirausaha di Kota Bekasi
}

\author{
Muhamad Hasan ${ }^{1}$, Ahmad Hafidzul Kahfi' ${ }^{2}$, Doni Purnama Alam Syah ${ }^{3}$ \\ ${ }^{1}$ STMIK Nusa Mandiri \\ e-mail: muhamadh0608@bsi.ac.id \\ ${ }^{2}$ STMIK Nusa Mandiri \\ e-mail: ahmadhaf0601@bsi.ac.id \\ ${ }^{3}$ STMIK Nusa Mandiri \\ e-mail: doni.dpa@icloud.com
}

\begin{abstract}
Intisari
Technopreneur dibutuhkan sebagai kunci keberhasilan negara dalam membangun perekonomian bangsa yang lebih baik. Dengan memanfaatkan teknologi menjadikan peluang adanya mobile application dalam menunjang keberhasilan masyarakat berwirausaha dengan menganalisis faktor-faktor yang mempengaruhi penggunanan mobile application. Untuk mengetahui penerimaan sistem yang digunakan pada mobile application, digunakan model TAM (Technology Acceptance Model) yang dipengaruhi oleh dua faktor yaitu perceived ease of use dan perceived usefulness. Tujuan dari penelitian ini adalah untuk mengetahui seberapa besar pengaruh mobile application terhadap kegiatan wirasuaha di kota Bekasi dengan menggunakan fitur Go-Food pada mobile application Gojek. Hasil penelitian ini menunjukkan bahwa variabel bebas yang terdiri dari persepsi kemanfaatan dan persepsi kemudahan memberikan sumbangan sebesar $38,6 \%$ terhadap pengaruh mobile application dalam menunjang wirausaha.
\end{abstract}

Kata Kunci: Technopreneur, Mobile Application, Go-Food, TAM

\begin{abstract}
Technopreneur is needed as a key to the country's success in building a better nation's economy. By utilizing technology makes it an opportunity for mobile applications to support the success of the entrepreneurial community by analyzing the factors that influence the use of mobile applications. To find out the acceptance of the system used in mobile applications, the TAM (Technology Acceptance Model) model is used which is influenced by two factors: perceived ease of use and perceived usefulness. The purpose of this study was to find out how much influence the mobile application had on entrepreneurial activities in the city of Bekasi by using the Go-Food feature in the Gojek mobile application. The results of this study indicate that the independent variables consisting of perceptions of benefits and perceptions of convenience contribute $38.6 \%$ to the effect of mobile applications in supporting entrepreneurship.
\end{abstract}

Keywords : Technopreneur, Mobile Application, Go-Food, TAM

\section{Pendahuluan \\ Perkembangan internet yang makin pesat, menjadikan hampir setengah penduduk dunia menggunakan internet. Diimbangi dengan penggunaan mobile application di Indonesia diperkirakan mencapai seratus juta pengguna. Peningkatan pengguna mobile application berbanding terbalik dengan jumlah pengusaha di Indonesia yang hanya mencapai sekitar $1,65 \%$. Menurut ahli}

sosiologi David McClelland menyarankan bahwa, untuk dapat mempertahankan pertumbuhan optimal perekonomian negara, diperlukan peningkatan jumlah $2 \%$ pengusaha dari total populasi penduduk disuatu negara (Hardiani \& Anggadwita, 2016).

Salah satu kota di Indonesia yang telah mencapai pertumbuhan optimal perekonomian adalah kota Bekasi. Hingga tahun 2015 lalu jumlah UMKM di Kota 
Bekasi sudah mencapai lebih kurang 203 ribu. Dari jumlah tersebut dapat dikatakan bahwa pengusaha di Kota Bekasi sudah sebanding dengan jumlah ideal wirausaha di suatu wilayah yakni $2 \%$ dari total jumlah penduduk Kota Bekasi yang berjumlah sekitar 2,7 juta penduduk berdasarkan sensus penduduk pada tahun 2015. Namun tidak semua pengusaha di Kota Bekasi menggunakan mobile application dalam usahanya, khususnya usaha yang bergerak dibidang kuliner. Salah satu mobile application yang mendukung para pengusaha khusunya usaha dalam bidang kuliner adalah aplikasi gojek dengan fiturnya yang bernama Go-Food. Fitur ini memanfaatkan teknologi sebagai landasan dalam melakukan proses transaksi, dimana penggunaan teknologi dalam berwirausaha ini dinamakan dengan technopreneur.

Technopreneur dibutuhkan sebagai kunci keberhasilan negara dalam membangun perekonomian bangsa yang lebih baik. Dengan memanfaatkan teknologi menjadikan peluang adanya mobile application dalam menunjang keberhasilan masyarakat berwirausaha dengan menganalisis faktor-faktor yang mempengaruhi penggunanan mobile application. Untuk mengetahui penerimaan sistem yang digunakan pada mobile application, digunakan model TAM (Technology Acceptance Model) yang dipengaruhi oleh dua faktor yaitu perceived ease of use dan perceived usefulness. Tujuan dari penelitian ini adalah untuk mengetahui seberapa besar pengaruh mobile application terhadap kegiatan wirasuaha di kota Bekasi dengan menggunakan fitur Go-Food pada mobile application Gojek.

\subsection{Tinjauan Teori}

\section{A. Mobile Application}

Menurut Irwansyah \& Moniaga (2014:61) "Mobile Application adalah aplikasi perangkat lunak yang dibuat khusus untuk dijalankan di dalam tablet dan juga smartphone".

Sedangkan menurut (Irsan, 2015) "Aplikasi Mobile adalah perangkat lunak yang berjalan pada perangkat mobile seperti smartphone atau tablet PC".

Jadi bisa disimpulkan bahwa mobile application adalah sebuah aplikasi perangkat lunak yang hanya dapat digunakan pada perangkat smartphone dan tablet $P C$.
Aplikasi Mobile juga dikenal sebagai aplikasi yang dapat diunduh dan memiliki fungsi tertentu sehingga menambah fungsionalitas dari perangkat mobile itu sendiri. Untuk mendapatkan mobile application yang diinginkan, user dapat mengunduhnya melalui situs tertentu sesuai dengan sistem operasi yang dimiliki. Google Play dan iTunes merupakan beberapa contoh dari situs yang menyediakan beragam aplikasi bagi pengguna Android dan iOS untuk mengunduh aplikasi yang diinginkan.

\section{B. Technopreneurship}

Technopreneurship merupakan wirausaha yang kreatif dan inovatif dalam memanfaatkan dan mengabungkan teknologi sehingga menghasilkan suatu produk atau jasa mereka akan bertanggung jawab segala risiko yang akan terjadi (Nurfaizal, 2014).

Sedangkan pendapat dari (Purnomo \& Triyono, 2018) "Technopreneurship merupakan kemampuan seseorang dalam mengembangkan jiwa wirausaha dengan pemanfaatan teknologi baik dalam proses pembuatan maupun pemasaran yang sesuai dengan kompetensi keahlian masing-masing".

Dapat diambil kesimpulan bahwa technopreneurship merupakan pemanfaatan teknologi sebagai alat untuk memasarkan produk sesuai dengan kompetensi yang dimiliki seorang pengusaha.

\section{TAM (Technology Acceptance Model)}

TAM merupakan salah satu jenis teori yang menggunakan pendekatan teori perilaku (behavioral theory) yang banyak digunakan untuk mengkaji proses adopsi teknologi informasi (Fatmawati, 2015).

TAM merupakan salah satu jenis teori yang menggunakan pendekatan teori perilaku (behavioral theory) yang banyak digunakan untuk mengkaji proses adopsi teknologi informasi. Bagaimanapun yang namanya model yang bagus itu tidak hanya memprediksi, namun idealnya juga harus bisa menjelaskan. Rupanya dengan model TAM dan indikatornya memang sudah teruji dapat mengukur penerimaan teknologi. Dengan demikian menggunakan TAM maka akan mampu menjelaskan mengapa sistem informasi perpustakaan yang 
digunakan di perpustakaan bisa diterima atau tidak oleh pengguna.

Sesuai dengan istilah TAM, bahwa "A" singkatan dari "Acceptance" artinya penerimaan. Sehingga bisa dikatakan bahwa TAM merupakan suatu model analisis untuk mengetahui perilaku pengguna akan penerimaan teknologi. Jika melihat pengertian TAM dari Wikipedia, "TAM is an information systems theory that models how users come to accept and use a technology". Maksudnya yaitu TAM merupakan suatu teori sistem informasi yang modelnya bagaimana pengguna datang untuk menerima dan menggunakan teknologi.

Melalui TAM, asumsinya pada saat pengguna akan menggunakan mobile application yang baru maka ada 2 (dua) faktor yang mempengaruhinya, yaitu:

1. Persepsi Kemudahan Penggunaan (Ease of Use Perceived). Jika diaplikasikan untuk mobile application, maka maksudnya pengguna meyakini kalau mobile application tersebut mudah dalam penggunaannya sehingga tidak memerlukan usaha keras dan akan terbebas dari kesulitan. Hal ini mencakup kemudahan penggunaan sistem informasi sesuai dengan keinginan penggunanya. Hasil penelitian Davis (1989) menunjukkan jika persepsi kemudahan dapat menjelaskan alasan pengguna untuk menggunakan mobile application dan dapat menjelaskan kalau mobile application dapat diterima oleh pengguna.

2. Persepsi Kebermanfaatan (Usefulness Perceived) Hal ini dimaksudkan bahwa pengguna percaya bahwa dengan menggunakan mobile application tersebut akan meningkatkan kinerjanya. Hal ini menggambarkan manfaat sistem dari penggunanya yang berkaitan dengan berbagai aspek. Jadi dalam persepsi kebermanfaatan ini membentuk suatu kepercayaan untuk pengambilan keputusan apakah jadi menggunakan mobile application atau tidak. Asumsinya jika pengguna mempercayai mobile application berguna maka tentu akan menggunakannya, tetapi sebaliknya jika tidak maka jawabannya pasti tidak akan menggunakannya.

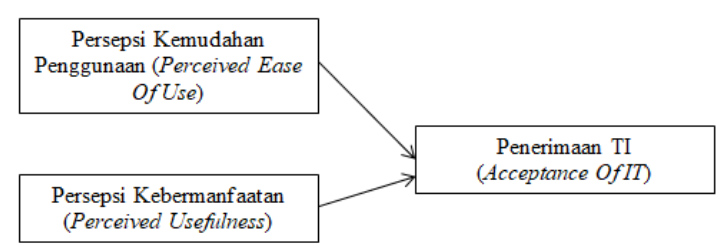

Sumber : Kharismaya, Dewi, Arisawati, \& Handayanna (2017)

\section{Gambar 1. Model Penerimaan Teknologi}

\section{Metode Penelitian}

Penelitian dilakukan dengan metode penelitian kuantitatif. Dalam penelitian ini menggunakan 2 variabel independen, yaitu: Kemanfaatan persepsian (perceived usefulness), Kemudahan persepsian (perceived easy of use) dan 1 variabel dependen, yaitu: penerimaan terhadap TI (Acceptanceof IT).

Tabel 1. Indikator-indikator Konstruk Penelitian

\begin{tabular}{|c|c|}
\hline $\begin{array}{l}\text { Konstruk } \\
\text { TAM }\end{array}$ & Indikator \\
\hline \multirow{4}{*}{ PEOU } & 1. Mudah dipelajari \\
\hline & 2. Jelas dan mudah dipahami \\
\hline & 3. Fleksibel \\
\hline & 4. Mudah menjadi mahir \\
\hline \multirow{4}{*}{ PU } & 1. Mempercepat Pekerjaan \\
\hline & 2. Meningkatkan Kinerja \\
\hline & 3. Efektivitas \\
\hline & 4. Mempermudah pekerjaan \\
\hline \multirow{4}{*}{$\begin{array}{l}\text { Acceptance of } \\
I T\end{array}$} & 1. Selalu Menggunakan \\
\hline & 2. Selalu Mengakses \\
\hline & 3. Kepuasan Menggunakan \\
\hline & $\begin{array}{l}\text { 4. Memberikan Masukan } \\
\text { untuk Menggunakan }\end{array}$ \\
\hline
\end{tabular}

Penelitian ini dimulai dari proses pengumpulan data dengan menggunakan kuesioner yang diisi oleh responden melalui aplikasi google form, kemudian dilakukan Uji Validitas dan Uji Reliabilitas terhadap kuesioner tersebut. Selanjutnya setelah kuesioner dianggap valid dan reliabel, maka dilakukan analisis data untuk menguji pengaruh kedua variabel penentu penerimaan teknologi dengan menggunakan Regresi Linear Sederhana dan dilanjutkan dengan analisis-analisis, yaitu:

1) Uji t, untuk mengetahui apakah secara parsial kemudahan, kemanfaatan 
berpengaruh secara signifikan atau tidak terhadap variabel penerimaan sistem.

2) Koefisien determinasi, bertujuan untuk mengukur seberapa jauh kemampuan model dalam menerangkan variasi variabel dependen.

\section{Hasil dan Pembahasan}

\subsection{Data Demografi}

Data demografi responden pada penelitian ini, diklasifikasikan berdasarkan jenis kelamin. Berdasarkan data pada tabel tersebut, seluruh responden berkontribusi $100 \%$ terhadap penelitian ini.

Tabel 1. Profil Responden Penelitian

\begin{tabular}{|c|c|c|}
\hline Jenis Kelamin & Jumlah & Persentase \\
\hline Laki-laki & 21 & $42 \%$ \\
\hline Perempuan & 29 & $58 \%$ \\
\hline Total & $\mathbf{5 0}$ & $\mathbf{1 0 0 \%}$ \\
\hline
\end{tabular}

Dari Tabel 1, diperoleh responden sebanyak 50 orang, dengan pembagian laki-laki sebesar $42 \%$ atau berjumlah 21 orang, sedangkan untuk perempuan sebesar $58 \%$ atau berjumlah 29 orang.

\subsection{Uji Validitas}

Jika rhitung $>$ rtabel, maka pernyataan tersebut dapat dinyatakan valid. Terdapat 12 butir pernyataan yang ditunjukan oleh Corrected Item-Total Correlation atau (rhitung).

Tabel 2. Hasil Uji Validitas

\begin{tabular}{|c|c|c|c|}
\hline No & $\begin{array}{c}\text { Rhitung } \\
\text { (Corrected } \\
\text { Item-Total } \\
\text { Correlation) }\end{array}$ & Rtabel & Kesimpulan \\
\hline 1 & 0,629 & 0,279 & Valid \\
\hline 2 & 0,558 & 0,279 & Valid \\
\hline 3 & 0,734 & 0,279 & Valid \\
\hline 4 & 0,752 & 0,279 & Valid \\
\hline 5 & 0,698 & 0,279 & Valid \\
\hline 6 & 0,780 & 0,279 & Valid \\
\hline 7 & 0,795 & 0,279 & Valid \\
\hline 8 & 0,464 & 0,279 & Valid \\
\hline 9 & 0,611 & 0,279 & Valid \\
\hline 10 & 0,434 & 0,279 & Valid \\
\hline 11 & 0,816 & 0,279 & Valid \\
\hline 12 & 0,713 & 0,279 & Valid \\
\hline
\end{tabular}

Sumber : Hasil Penelitian (2018)

Pada Tabel 2 seluruh skor Corrected Item-Total Correlation (rhitung) menunjukan lebih besar dari rtabel sebesar 0,197 . Hal ini menunjukan bahwa setiap pernyataan yang diukur pada variabel persepsi kemanfaatan adalah valid.

\subsection{Uji Reliabilitas}

Uji reliabilitas yang digunakan dalam penelitian ini menggunakan metode Cronbach's Alpha. Pengujian instrumen dinyatakan reliabel, jika harga koefisien reliabilitas $>0,60$.

Tabel 3. Hasil Uji Reliabilitas

\begin{tabular}{|c|c|}
\hline Cronbach's Alpha & N of items \\
\hline 0,879 & 12 \\
\hline
\end{tabular}

Berdasarkan Tabel 3 diketahui bahwa variabel memiliki Cronbach's Alpha lebih besar dari 0,60 yang artinya data sudah reliabel.

\subsection{Hasil Uji Regresi Linear Sederhana}

Tabel 4. Hasil Uji Regresi Linear Sederhana Coefficients $^{\mathrm{a}}$

\begin{tabular}{|c|c|c|c|c|c|}
\hline \multirow[t]{2}{*}{ Model } & \multicolumn{2}{|c|}{$\begin{array}{l}\text { Unstandardized } \\
\text { Coefficients }\end{array}$} & $\begin{array}{l}\text { Standar } \\
\text { dized } \\
\text { Coeffici } \\
\text { ents }\end{array}$ & \multirow[t]{2}{*}{$\mathrm{t}$} & \multirow[t]{2}{*}{ Sig. } \\
\hline & B & $\begin{array}{l}\text { Std. } \\
\text { Error }\end{array}$ & Beta & & \\
\hline $\begin{array}{c}\text { (Constant) } \\
\text { Variabel } \\
\text { Bebas }\end{array}$ & $\begin{array}{c}3,262 \\
337\end{array}$ & $\begin{array}{c}1,720 \\
, 061\end{array}$ & 621, & $\begin{array}{l}1,896 \\
5,488\end{array}$ & $\begin{array}{l}, 064 \\
000\end{array}$ \\
\hline
\end{tabular}

Dari Tabel 4 diatas, diperoleh persamaan regresi sebagai berikut :

$$
Y=3,262+0,337 X
$$

Dengan Variabel Bebas didapat dari persepsi kemanfaatan dan persepsi kemudahan penggunaan yang memiliki arti sebagai berikut :

1. Angka konstan bernilai 0,888 yang mengandung arti bahwa nilai konsistensi variabel terikat adalah sebesar 3,262.

2. Sementara nilai koefisien regresi bernilai 0,337 yang berarti setiap penambahan $1 \%$ tingkat kemudahan penggunaan dan kemanfaatan $(X)$, maka penerimaan $\mathrm{TI}$ (Y) akan meningkat sebesar 0,337.

\subsection{Hasil Uji Hipotesis}

a. Hasil Uji T

Uji $\mathrm{T}$ digunakan untuk mengetahui apakah secara parsial persepsi kemanfaatan dan persepsi kemudahan berpengaruh secara signifikan atau 
tidak terhadap variabel penerimaan aplikasi.

Tabel 5. Hasil Uji T
Coefficients $^{\mathbf{a}}$
\begin{tabular}{|c|c|c|}
\hline Model & $\mathrm{t}$ & Sig. \\
& & \\
\hline (Constant) & 1,896 &, 064 \\
Variabel Bebas & 5,488 &, 000 \\
\hline
\end{tabular}

sebagai berikut:

Dari Tabel 5 dapat dianalisa Kriteria pengujian uji $\mathrm{T}$ :

a. Jika nilai sig $<0,05$ atau thitung $>$ tabel maka terdapat pengaruh yang signifikan antara variabel $\mathrm{X}$ terhadap variabel $Y$.

b. Jika nilai sig $>0,05$ atau thitung $<t_{\text {tabel }}$ maka tidak terdapat pengaruh yang signifikan antara variabel $X$ terhadap variabel $Y$.

Berdasarkan perhitungan SPSS, untuk nilai thitung Variabel Bebas adalah 5,488 dan nilai tabel sebesar 2,011 dengan tingkat signifikansi sebesar 0,05 . Hasil ini menunjukan perbandingan antara thitung dengan tabel yaitu $5,488>2,011$ dan perbandingan tingkat signifikansi $0,000<$ 0,05 . Dapat diambil kesimpulan bahwa variabel bebas yang terdiri dari persepsi kemanfaatan dan persepsi kemudahan memiliki pengaruh yang signifikan terhadap mobile application dalam menunjang wirausaha.

b. Koefisien Determinasi Simultan $\left(\mathrm{R}^{2}\right)$ Koefisien determinasi bertujuan untuk mengukur seberapa jauh kemampuan model dalam menerangkan variasi variabel dependen. Nilai koefisien determinasi antara nol dan satu. Nilai koefisien determinasi dapat dilihat pada tabel 6 .

Tabel 6. Hasil Uji Koefisien Determinasi Simultan

\begin{tabular}{|c|c|c|c|c|}
\hline Model & $R$ & $\begin{array}{c}R \\
\text { Square }\end{array}$ & $\begin{array}{c}\text { Adjusted } \\
\text { R Square }\end{array}$ & $\begin{array}{c}\text { Std. Error } \\
\text { of the } \\
\text { Estimate }\end{array}$ \\
\hline 1 &, $621^{\mathrm{a}}$ &, 386 &, 373 & 1,583 \\
\hline
\end{tabular}

Hasil perhitungan dengan menggunakan program SPSS, berdasarkan
Tabel 6 dapat diketahui bahwa koefisien determinasi ( $R$ Square) yang diperoleh sebesar 0,386. Hal ini berarti 38,6\% pengaruh mobile application dalam menunjang wirausaha dapat dijelaskan oleh variabel persepsi kemanfaatan dan persepsi kemudahan. Sedangkan sisanya $61,4 \%$ dipengaruhi oleh variabel-variabel lain yang tidak diteliti dalam penelitian ini.

\subsection{Pengaruh Persepsi Kemanfaaran dan Persepsi Kemudahan (X) Terhadap Penerimaan Teknologi (Y) dalam Menunjang Wirausaha}

Hasil pengujian hipotesis sebagai berikut:

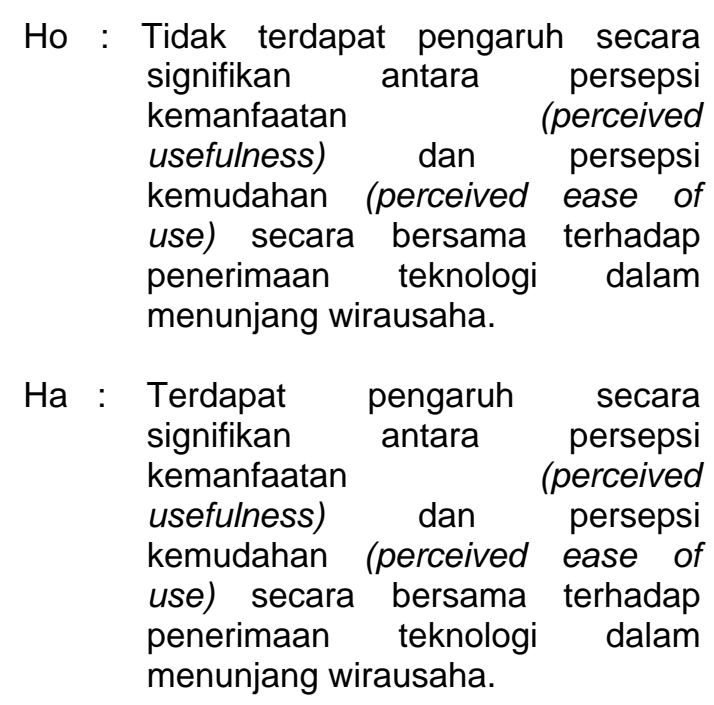

Berdasarkan hasil Uji $\mathrm{T}$ dengan output spss yang menunjukan bahwa thitung lebih besar dari tabel dan signifikasi sebesar nol menyatakan bahwa variabel persepsi kemanfaatan dan persepsi kemudahan secara bersama memiliki pengaruh yang signifikan terhadap penerimaan teknologi dalam menunjang wirausaha. Hasil tersebut diperkuat dengan uji Koefisien Determinasi Simultan ( $R$ Square) yang mengukur seberapa jauh kemampuan model dalam menerangkan variabel dependen. Diperoleh hasil sebesar sepertiga lebih dari seratus persen untuk variabel persepsi kemanfaatan dan persepsi kemudahan untuk menjelaskan penerimaan teknologi Mobile Application dalam menunjang wirausaha.

\section{Kesimpulan}

Simpulan yang diperoleh dari penelitian ini adalah bahwa analisis pengaruh mobile application dalam 
menunjang keberhasilan wirausaha masyarakat kota Bekasi dapat dipengaruhi oleh dua faktor, yakni persepsi kemanfaatan dan persepsi kemudahan penggunaan. Persepsi kebermanfaatan (usefulness perceived) mengandung empat indikator yang mempengaruhi dalam mengidentifikasi pengaruh mobile application, antara lain : mempercepat pekerjaan, meningkatkan kinerja, efektifitas, dan mempermudah pekerjaan. Persepsi kemudahan penggunaan (ease to use perceived) juga memiliki empat indikator yang mempengaruhi, yaitu mudah dipelajari, jelas dan mudah dipahami, fleksibel, serta mudah untuk menjadi terampil/mahir.

\section{Referensi}

Fatmawati, E. (2015). Technology Acceptance Model (TAM) Untuk Menganalisis Penerimaan Terhadap Sistem Informasi Perpustakaan, $0(1)$, 1-13.

Hardiani, K. B. I., \& Anggadwita, G. (2016). Analisis Identifikasi Rancangan Mobile Application Untuk Menunjang Keberhasilan Berwirausaha Masyarakat, 3(2), 990-994.
Irsan, M. (2015). Rancang Bangun Aplikasi Mobile Notifikasi Berbasis Android Untuk Mendukung Kinerja Di Instansi Pemerintahan.

Irwansyah, E., \& Moniaga, J. V. (2014). Pengantar Teknologi Informasi. Yogyakarta: Deepublish.

Kharismaya, C., Dewi, L. S., Arisawati, E., \& Handayanna, F. (2017). Analisa Kemanfaatan Dan Kemudahan Terhadap Penerimaan Sistem OPAC Menggunakan Metode TAM, (1), 3747.

Nurfaizal, Y. (2014). Perilaku Technopreneur Mahasiswa Teknik Informatika : Tinjauan Pada SelfSufficiency, 14(2), 13-25.

Purnomo, S., \& Triyono, M. B. (2018). Efektifitas Technopreneurship Dengan Model Pembelajaran Cooperative Learning By Technopreneur For SMK Untuk Siswa Di SMK, 6(4).

Sumarlinda, S. (2015). Evaluasi Implementasi Sistem Kartu Rencana Studi Berbasis Web Dengan Technology Acceptance Model (Studi Kasus STMIK Duta Bangsa Surakarta). (1), 83-91. 